\title{
The Exopolysaccharide Produced by Lactobacillus paracasei IJH-SONE68 Prevents and Ameliorates Inflammatory Responses in DSS-Induced Ulcerative Colitis
}

\author{
Masafumi Noda ${ }^{1}$, Narandalai Danshiitsoodol ${ }^{1}$ (D), Keishi Kanno ${ }^{2,3}{ }^{\mathbb{D}}$, Tomoyuki Uchida ${ }^{3,4}$ \\ and Masanori Sugiyama ${ }^{1, *}$ \\ 1 Department of Probiotic Science for Preventive Medicine, Graduate School of Biomedical and Health Sciences, \\ Hiroshima University, Hiroshima 734-8551, Japan; bel@hiroshima-u.ac.jp (M.N.); \\ naraa@hiroshima-u.ac.jp (N.D.) \\ 2 Department of General Internal Medicine, Hiroshima University Hospital, Kasumi 1-2-3, Minami-ku, \\ Hiroshima 734-8551, Japan; kkanno@hiroshima-u.ac.jp \\ 3 Department of Clinical Pharmaceutical and Therapeutics, Hiroshima University, Kasumi 1-2-3, Minami-ku, \\ Hiroshima 734-8551, Japan; t.uchida@asahi-techneion.co.jp \\ 4 Sone Farm Co., Ltd., Shinjuku, Shinjuku-ku, Tokyo 160-0022, Japan \\ * Correspondence: sugi@hiroshima-u.ac.jp; Tel.: +81-82-257-5280
}

Citation: Noda, M.; Danshiitsoodol, N.; Kanno, K.; Uchida, T.; Sugiyama, M. The Exopolysaccharide Produced by Lactobacillus paracasei IJH-SONE68 Prevents and Ameliorates Inflammatory Responses in DSS-Induced Ulcerative Colitis. Microorganisms 2021, 9, 2243. https://doi.org/10.3390/ microorganisms 9112243

Academic Editors: Flavia Indrio, Beatrice Vitali and Carola Parolin

Received: 26 September 2021 Accepted: 26 October 2021

Published: 28 October 2021

Publisher's Note: MDPI stays neutral with regard to jurisdictional claims in published maps and institutional affiliations.

Copyright: (c) 2021 by the authors. Licensee MDPI, Basel, Switzerland. This article is an open access article distributed under the terms and conditions of the Creative Commons Attribution (CC BY) license (https:/ / creativecommons.org/licenses/by/ $4.0 /)$.

\begin{abstract}
Inflammatory bowel disease (IBD) is an autoimmune disease characterized by chronic inflammation of the gastrointestinal tract. IBD includes Crohn's disease (CD) and ulcerative colitis (UC). CD can occur in any part of the gastrointestinal tract, whereas UC mainly occurs in the colon and rectum. We previously demonstrated that a novel exopolysaccharide (EPS) produced by a plantderived bacterium, Lactobacillus paracasei IJH-SONE68, prevents and improves the inflammation in contact dermatitis model mice via oral administration. To evaluate the preventive effect of the EPS against other inflammatory diseases, in the present study, we employed dextran sulfate sodium (DSS)-induced UC model mice. The stool consistency, hematochezia, and colonic atrophy of the mice were improved by the orally administered EPS. We also evaluated the cytokine transcription. Overexpression of the mouse macrophage inflammatory protein 2 mRNA in the colon as a functional homolog of human interleukin-8 was decreased by the orally administered EPS. However, the expression of interleukin-10, which is known as an anti-inflammatory cytokine, was stimulated in the EPS-administrated group. Based on these results, we conclude that the IJH-SONE68-derived EPS is a promising lead material for the development of drugs useful in treating inflammatory diseases such as UC.
\end{abstract}

Keywords: inflammatory bowel disease (IBD); ulcerative colitis (UC); lactic acid bacteria (LAB); Lactobacillus paracasei; exopolysaccharide (EPS)

\section{Introduction}

The number of individuals worldwide who suffer from inflammatory bowel disease (IBD) is increasing. Historically, IBD was most prevalent in North Americans and Europeans. However, the recent shift in dietary and lifestyle patterns in newly industrialized countries, such as those in Asia, Africa, South America, and Eastern Europe, has caused a significant rise in the incidence of IBD [1]. In the latest report, there were 6.8 million cases of IBD globally in 2017 [2].

IBD patients may present with symptoms such as chronic diarrhea, rectal bleeding, abdominal pain, and weight loss. IBD is defined as an autoimmune disease characterized by chronic inflammation of the gastrointestinal tract caused by a dysfunction of the innate immune system [3]. The two major subtypes of IBD are Crohn's disease (CD) and ulcerative colitis (UC), both having complex pathological spectra [3-5]. CD can occur in any part of the gastrointestinal tract, from the mouth to the anus. Predilection sites for the disease are 
the small intestine, colon, and anus. The areas of inflammation in the gastrointestinal tract are patchy and next to healthy tissue. UC usually occurs in the colon, and the damaged areas continuously spread to the rectum.

The exact causes of both diseases are unknown. However, it has been suggested that when some environmental triggers incorrectly activate the immune system in patients, their abnormal immune responses continuously attack their gastrointestinal tracts, resulting in chronic inflammation. Since CD and UC are chronic inflammatory diseases, they are not medically curable once they have developed [6]. Patients must continue medical treatment with the aim of decreasing inflammation, but the drugs show limited efficacy in remission and some significant side effects with long-term use [7]. Therefore, the development of more effective therapeutic agents and treatments as soon as possible is desired.

Lactic acid bacteria (LAB) are generally nonpathogenic Gram-positive bacteria and are known as typical probiotics, which are defined as living microorganisms that confer health benefits to human hosts [8]. We previously isolated some exopolysaccharide (EPS)-producing LAB strains. Interestingly, those EPSs have displayed a hyaluronidaseinhibitory effect [9-11] that has been reported to correlate with histamine-release inhibition in inflammatory reactions through immunoglobulin E (IgE)-mediated mast cell degranulation [12-14]. Among EPS-producing LAB strains, we found that the Lactobacillus $(L b$.) paracasei IJH-SONE68-derived EPS prevents and improves inflammation in picryl chloride-induced contact dermatitis via oral administration in model mice [15]. We considered that the IJH-SONE68 strain-derived EPS may modulate immune responses under inflammatory conditions. Therefore, to evaluate in this study whether the EPS has a preventive effect against other inflammatory diseases other than contact dermatitis [15], we used dextran sulfate sodium-induced UC model mice to evaluate the preventive and improving effects of the IJH-SONE68-derived EPS against UC.

\section{Materials and Methods}

\subsection{Bacterial Strains and Culture Conditions}

For precultivation of $L b$. paracasei IJH-SONE68, a de Man, Rogosa, and Sharpe (MRS) medium (Merck KGaA, Darmstadt, Germany) was used. The IJH-SONE68 strain has been deposited in the National Institute of Technology and Evaluation (NITE) Patent Microorganisms Depositary (NPMD) in Japan as NITE P-02242. Brain heart infusion (BHI) broth was used as the culture medium for Salmonella enterica serovar Typhimurium (S. Typhimurium) and Campylobacter (C.) jejuni.

\subsection{Purification of EPSS}

Purification of the EPSs produced from the IJH-SONE68 strain was performed according to previous reports $[9,15]$. Briefly, the IJH-SONE68 strain was inoculated into a fresh modified semi-defined medium (SDM) $[16,17]$ supplemented with $0.2 \%(v / v)$ vitamin mixture and $0.1 \%(v / v)$ trace element solution instead of yeast nitrogen bases. After 2 days of stationary cultivation, the cultured broth was boiled for $30 \mathrm{~min}$, and then a 100\% $(w / v)$ trichloroacetic acid (TCA) solution was added to the culture broth at a final concentration of $4 \%(v / v)$. The cells were removed by centrifugation, and the obtained culture supernatant was added to the same volume of acetone in order to precipitate crude EPSs. After centrifugation, the crude EPSs were dissolved into a $50 \mathrm{mM}$ Tris- $\mathrm{HCl}$ buffer ( $\mathrm{pH}$ 8.0) and treated with nuclease and protease. The EPSs were dialyzed against sterile distilled water using Amicon Ultra (MWCO = 10 kDa, Merck Millipore, Ltd., Carrigtwohill, Co. Cork, Ireland) to obtain a purified EPS mixture, and the sample was lyophilized and stored at $4{ }^{\circ} \mathrm{C}$ until the IL-8 release inhibition assay was used.

The neutral and acidic EPSs were further separated via column chromatography using an anion exchange resin (TOYOPEARL DEAE-650M, Tosoh Bioscience, Tokyo, Japan) as described previously [10]. After dialysis against sterile distilled water using Amicon Ultra $(\mathrm{MWCO}=10 \mathrm{kDa})$, each EPS sample was lyophilized and stored at $4{ }^{\circ} \mathrm{C}$ until use. 


\subsection{IL-8 Release Inhibition Assay}

The assay using Caco-2 cells was performed according to previous reports $[18,19]$. Briefly, Caco-2 cells were precultured in Dulbecco's modified Eagle's medium (DMEM) (low glucose, FUJIFILM Wako Pure Chemical Co., Ltd., Osaka, Japan) containing 10\% $(v / v)$ fetal bovine serum (FBS), $2 \mathrm{mM}$ L-glutamine, $100 \mathrm{U} / \mathrm{mL}$ penicillin, and $100 \mu \mathrm{g} / \mathrm{mL}$ streptomycin in an atmosphere of $5 \% \mathrm{CO}_{2}$ at $37^{\circ} \mathrm{C}$. The cultured Caco- 2 cells were resuspended into the same fresh medium, and a total of $2.0 \times 10^{5}$ cells were seeded in a 24 -well cell-culture plate and cultured to $70 \%$ confluence under the same condition. Before starting the experiments, the confluent monolayers were washed and starved in serum-free DMEM. The cells were preincubated for $30 \mathrm{~min}$ with a $5 \%(v / v)$ purified EPS mixture $(1 \mathrm{mg} / \mathrm{mL})$ and then stimulated for up to $2 \mathrm{~h}$ with a freshly prepared S. Typhimurium or C. jejuni suspension at a multiplicity of infection of 10 . The bacterial infection was terminated with $100 \mu \mathrm{g} / \mathrm{mL}$ gentamicin, and the cell monolayers were further incubated for $24 \mathrm{~h}$. The cell-free supernatants were collected, and concentrations of the released IL-8 were determined via enzyme-linked immune sorbent assay (ELISA) (BioLegend, Inc., San Diego, CA, USA) according to the manufacturer's instruction. At least four replicates of all assays were performed. The culture without bacterial stimulation was used as a negative control (NC), and one treated with an S. Typhimurium or C. jejuni suspension at a multiplicity of infection of 10 was used as a positive control (PC).

\subsection{Animals and Rearing Conditions}

Seven-week-old male-specific-pathogen-free (SPF) C57BL/6J Jms Slc mice were purchased from Japan SLC, Inc. (Shizuoka, Japan). The mice were weighed prior to experimentation and then divided into experimental groups of five mice each and housed in a plastic cage. All mice were maintained with free access to water and a standard rodentchow diet (MF diet, Oriental Yeast Co., Ltd., Tokyo, Japan) under conditions of $20-26{ }^{\circ} \mathrm{C}$, 40-60\% humidity, and a $12 \mathrm{~h}$ light/12 h dark cycle. Each mouse was distinguished by different-color markings on their tails using Animal Marker felt pens (Fuchigami Kikai Co., Ltd., Kyoto, Japan). After the experimental period, the mice were euthanized by the inhalation of anesthesia with isoflurane. The animal experimental protocol was approved by the committee of the Research Facilities for Laboratory Animal Science of Hiroshima University (approval number A18-2, approval on 3 April 2018), and the animal experiment in the present study was conducted in accordance with the Guidelines for the Care and Use of Laboratory Animals of Hiroshima University after approval of the protocol.

\subsection{Preparation and Evaluation of the DSS-Induced UC Model in Mice}

The 20 mice were divided into four experimental groups (five mice each) as follows: a group without UC induction (negative control group, NC); a group with UC induction but without treatment (positive control group, PC); a group with UC induction and neutral-EPS (N-EPS) administration; and a group with UC induction and acidic-EPS (A-EPS) administration.

After 7 days of pre-administration of the EPS solution, DSS was added to the mice's drinking water at a final concentration of $3 \%(w / v)$ to induce UC, except for the NC group. During the other two-week UC-induction period, the body weight and the stool consistency, and hematochezia scores of all mice were recorded. The totals of both scores were evaluated as a disease activity index (Table 1).

After the experimental period, the mice were euthanized by the inhalation of anesthesia with isoflurane. The length of colon collected from each mouse was measured, and the middle part was cut into about $5 \mathrm{~mm}$ pieces and stored for use in further analyses.

\subsection{Myeloperoxidase (MPO) Activity Assay}

Each PBS-washed colon piece (10-25 mg) was weighed and transferred into a $1.5 \mathrm{~mL}$ microcentrifuge tube with $100 \mathrm{mg}$ of glass beads (acid-washed $\leq 106 \mu \mathrm{m}$, Sigma-Aldrich Co., LLC, St. Louis, MO, USA). Each colon sample was homogenized with a pestle in a 
microtube, and then a $50 \mathrm{mM}$ potassium phosphate buffer $(\mathrm{pH} 6.0)$ containing $0.5 \%(w / v)$ hexadecyltrimethylammonium bromide (HTAB) was added at a volume of $40 \mu \mathrm{L} / \mathrm{mg}$ of tissue. After gentle mixing, the glass beads and cell debris were removed from the homogenized sample by centrifugation at $13,000 \times g$ for $10 \mathrm{~min}$ at room temperature (RT). The obtained supernatant was transferred into a fresh tube and stored at $-80{ }^{\circ} \mathrm{C}$ until use as an enzyme solution.

Table 1. The criteria for scoring the stool consistency and hematochezia conditions.

\begin{tabular}{cll}
\hline Score & \multicolumn{1}{c}{ Stool Consistency } & \multicolumn{1}{c}{ Hematochezia } \\
\hline 0 & Normal stools & Normal stools \\
& Soft pellets; & Pale red to red-colored stools; \\
can be picked up by tweezers & blood spreads only surface on the stools \\
& Loose stools; & Red to deep red-colored stools; \\
cannot be picked up by tweezers & Dlood spreads in the stools \\
2 & Diarrhea & gross bleeding \\
\hline
\end{tabular}

The MPO activity was measured in accordance with the previously reported protocol [20]. The reaction buffer was prepared by adding $o$-dianisidine dihydrochloride and $\mathrm{H}_{2} \mathrm{O}_{2}$ to a $5 \mathrm{mM}$ potassium phosphate buffer $(\mathrm{pH} 6.0)$ at concentrations of $0.53 \mathrm{mM}$ and $44 \mu \mathrm{M}$, respectively. After mixing $7 \mu \mathrm{L}$ of the enzyme solution and $200 \mu \mathrm{L}$ of the reaction buffer in a 96-well plate, absorbance was measured at $450 \mathrm{~nm}\left(A_{450}\right)$ using a spectrophotometer (iMark Microplate reader, Bio-Rad Laboratories, Inc., Hercules, CA, USA) at 3 min intervals. The MPO activity was calculated in units per $\mathrm{mg}$ of tissue. One unit of MPO is defined as the enzyme amount that degrades $1 \mu \mathrm{mol} / \mathrm{min}$ of $\mathrm{H}_{2} \mathrm{O}_{2}$, determined as $\left(\Delta A_{450} / \mathrm{min}\right) \times\left(1.13 \times 10^{-2}\right)[20]$.

\subsection{Preparation, Manipulation, and qRT-PCR Analysis of RNA}

Total RNA was extracted and purified from each colon tissue using a NucleoSpin RNA II kit (Macherey-Nagel GmbH \& Co. KG, Düren, Germany) in accordance with the manufacturer's instructions. The RNA was converted to cDNA using the ReverTra Ace qPCR RT master mix with gDNA remover (Toyobo, Osaka, Japan) in accordance with the manufacturer's instruction manual. The qRT-PCR was conducted on the PikoReal Real-Time PCR System (Thermo Fisher Scientific, Waltham, MA, USA), and the reaction was performed using the KAPA SYBR Fast qPCR Kit (Kapa Biosystems, Wilmington, MA, USA). The PCR was performed under the following conditions: an initial denaturation for $30 \mathrm{~s}$ at $95^{\circ} \mathrm{C}$, followed by 40 cycles of $5 \mathrm{~s}$ denaturing at $95^{\circ} \mathrm{C}$ and $30 \mathrm{~s}$ at $60^{\circ} \mathrm{C}$. The relative transcriptional levels of the target genes were normalized to that of the reference gene ( $\beta$-actin) using the $\Delta \Delta C_{\mathrm{T}}$ method. The primer sets in this experiment are listed in Table 2.

\subsection{Statistical Analyses}

Statistical analyses conducted in the present study were performed using SPSS 17.0 software (IBM Corporation, New York, NY, USA). Multiple comparisons of parameters were assessed using the Tukey-Kramer test [21].

\subsection{Histopathological Analysis}

Mouse colons obtained after sacrifice were fixed with a $4 \%(w / v)$ formaldehyde solution and then embedded in a paraffin block. The histopathological tissue sections were cut from the block and placed on glass slides. The sections were stained with hematoxylin and eosin (HE). Tissue sections were monitored and recorded using an OLYMPUS IX71 research inverted system microscope (Olympus Corporation, Tokyo, Japan) with controlling and image-capturing software. The average crypt depth was determined from at least 50 independent measures per mouse tissue. 
Table 2. Primers for qRT-PCR used in this study.

\begin{tabular}{|c|c|c|}
\hline Name & Sequence $\left(5^{\prime} \rightarrow 3^{\prime}\right)$ & Target Products \\
\hline $\mathrm{m} \beta$-actin-F & GGGACGACATGGAGAAGA & $\beta$-actin \\
\hline $\mathrm{m} \beta$-actin- $\mathrm{R}$ & CATACAGGGACAGCACAG & \\
\hline $\mathrm{mCOX}-2-\mathrm{F}$ & TCAGTAGGTTTTTGCTGTGAGG & COX-2 \\
\hline mCOX-2-R & GTTCAATGGGCTGGAAGACA & \\
\hline miNOS-F & GAAGAAAACCCCTTGTGCTG & iNOS \\
\hline miNOS-R & TTCTGTGCTGTCCCAGTGAG & \\
\hline mTNF- $\alpha-F$ & CATCTTCTCAAAATTCGAGTGACAA & TNF- $\alpha$ \\
\hline mTNF- $\alpha-R$ & TGGGAGTAGACAAGGTACAACCC & \\
\hline mIL-6-F & GAGGATACCACTCCCAACAGACC & IL-6 \\
\hline mIL-6-R & AAGTGCATCATCGTTGTTCATACA & \\
\hline mMIP2-F & AGTGAACTGCGCTGTCAATG & MIP-2 \\
\hline mMIP2-R & CAAGGCAAACTTTTTGACCG & \\
\hline mIL-10-F & GGTTGCCAAGCCTTATCGGA & IL-10 \\
\hline mIL-10-R & ACCTGCTCCACTGCCTTGCT & \\
\hline mIL-12-F & AGGACTTGAAGATGTACCAG & IL-12 \\
\hline mIL-12-R & CTATCTGTGTGAGGAGGG & \\
\hline mIL-17-F & GCTCCAGAAGGCCCTCAGA & IL-17 \\
\hline mIL-17-R & AGCTTTCCCTCCGCATTGA & \\
\hline mIL-18-F & CAGGCCTGACATCTTCTGCAA & IL-18 \\
\hline mIL-18-R & TCTGACATGGCAGCCATTGT & \\
\hline
\end{tabular}

\section{Results}

\subsection{Effect of the IJH-SONE68-Derived EPS on the Release of IL-8 from Caco-2 Cells}

An ELISA was preliminarily used to evaluate any effect on IL-8 induction in the in vitro model. In the assay, a 2 -h stimulation of Caco-2 cells with S. Typhimurium or C. jejuni sufficiently induced IL-8 production, as compared with no stimulation. On the other hand, among the tested samples, the addition of the EPS mixture from the IJH-SONE68 strain significantly suppressed the pathogen-induced IL-8 expression (Supplementary Figure S1) without any inhibition of the viability of the Caco-2 cells.

\subsection{Preventive Effect of the IJH-SONE68-Derived EPS on DSS-Induced UC Model Mice 3.2.1. Disease Activity Index}

To evaluate the preventive and improving effects of EPSs on UC, DSS-induced UC model mice $[22,23]$ were used. Figure 1 shows the changes in stool consistency and hematochezia scores in each group. Both scores increased for the DSS-induced UC model mice. EPS administration repressed the scores slightly, but not significantly, during the first week of the experimental period. However, the stool consistency was significantly $(p<0.05)$ improved during the second week with oral administration of the A-EPS, whereas the hematochezia score improvement was not significant but did demonstrate a trend $(p=0.057)$. Moreover, the disease activity index (DAI), defined as the total of the stool consistency and hematochezia scores (Table 1), of the A-EPS administration also improved significantly $(p<0.01)$ during the same period (Figure $1 C)$.

\subsubsection{Colon Length}

Figure 2 shows the average colon length of the mice in each group. As compared with the normal group, the colon length of the DSS-treated mice was significantly $(p<0.01)$ shortened. Conversely, the administration of N-EPS or A-EPS resulted in the prevention of DSS-induced colon reduction with statistical trends $(p=0.052)$ or significance $(p<0.05)$, respectively. 
A

Stool consistency score
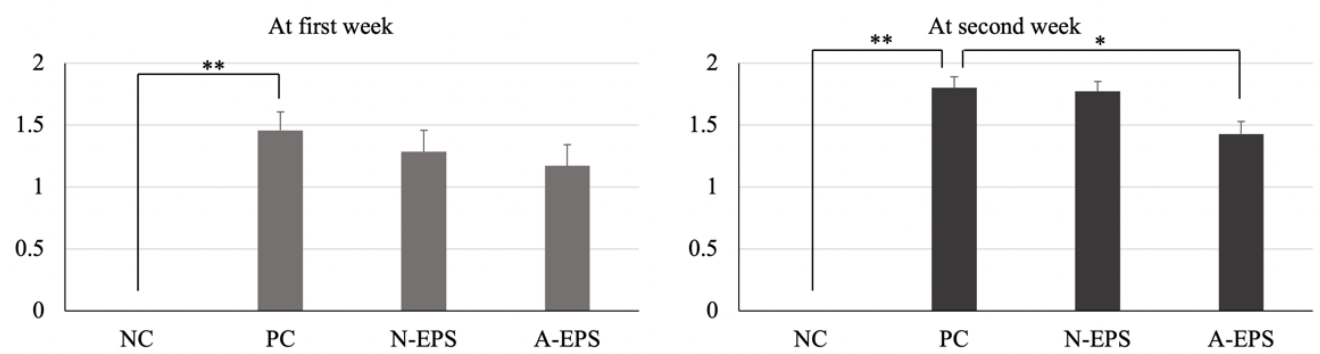

B

Hematochezia score
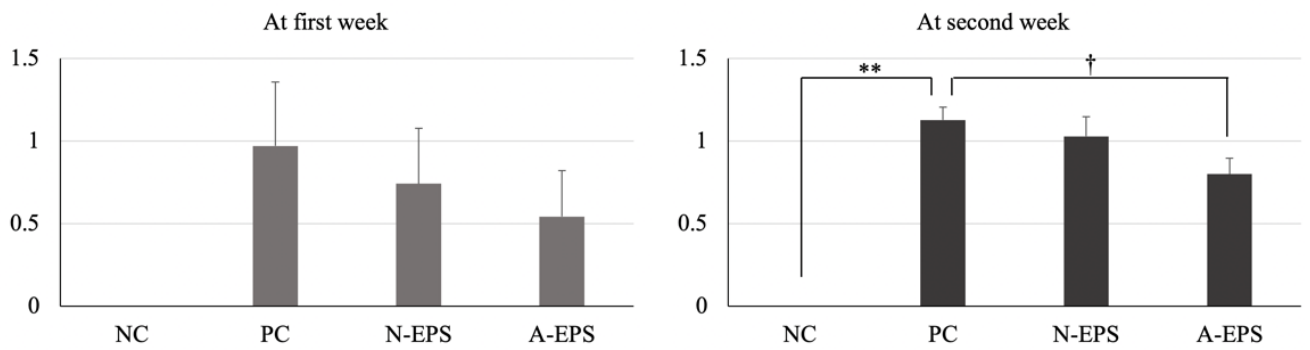

$\mathrm{C}$

Disease activity index
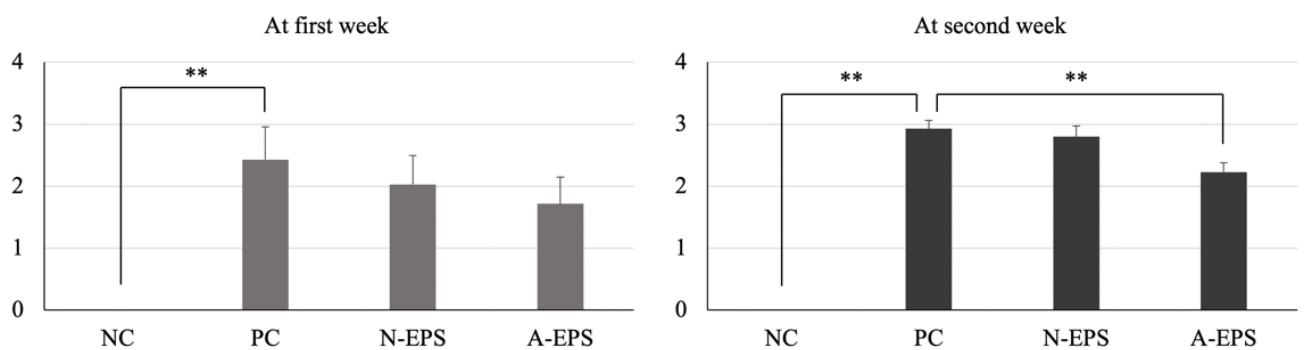

Figure 1. Effects of IJH-SONE68-derived EPSs in DSS-induced UC model mice on the changes in stool consistency score, hematochezia score, and disease activity index, which is defined as the total of the two scores (stool consistency and hematochezia). The right and left panels display changes in stool consistency score (A), hematochezia score (B), and disease activity index (C) at the first and the second week, respectively. The scores are indicated as weekly averaged ones for each group (mean \pm S.E., $n=7$ ). The scoring criteria for both are indicated in Table 1. Abbreviations used in the figure: NC, negative control group (without UC induction); PC, positive control group (without treatment); N-EPS, UC induction with N-EPS treatment; A-EPS, UC induction with A-EPS treatment. The statistical analyses were performed using the Tukey-Kramer multiple comparison test $\left({ }^{\dagger} p<0.1\right.$, ${ }^{*} p<0.05,{ }^{* *} p<0.01$, vs. PC).

\subsubsection{MPO Activity}

MPO activity has been reported to be used as a surrogate marker of inflammation [24]. After the extraction of proteins from the tissue of each colon, the MPO activity was measured using a colorimetric assay. Figure 3 shows that the MPO activity was significantly $(p<0.05)$ increased in the DSS-treated positive control group. At the same time, in the A-EPS-administration group, but not in the N-EPS-administration group, MPO activity 
was repressed by about $50 \%$ with no statistical significance, which manifests prevention against DSS-induced chronic inflammation.

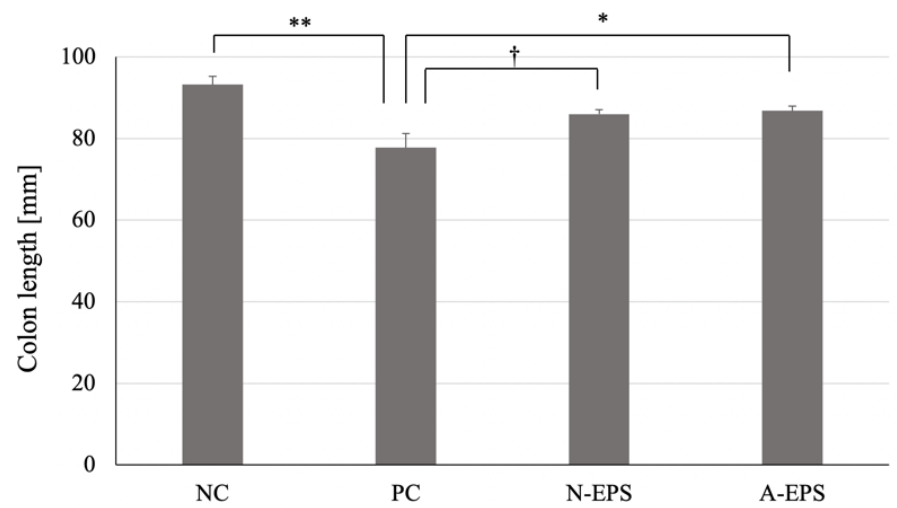

Figure 2. Effects of IJH-SONE68-derived EPSs in DSS-induced UC model mice on colon length after 14 days of treatment. Abbreviations used in the figure: NC, negative control group (without UC induction); PC, positive control group (without treatment); N-EPS, UC induction with N-EPS treatment; A-EPS, UC induction with A-EPS treatment. The statistical analyses were performed using the Tukey-Kramer multiple comparison test $\left({ }^{\dagger} p<0.1,{ }^{*} p<0.05,{ }^{* *} p<0.01\right.$, vs. PC). Data are indicated by mean \pm S.E. $(n=4-5)$.

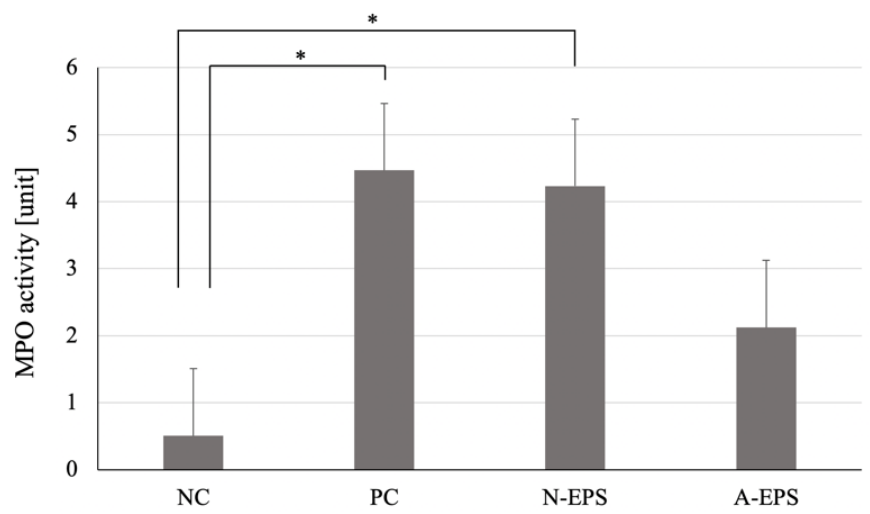

Figure 3. Effects of IJH-SONE68-derived EPSs in DSS-induced UC model mice on the MPO activity of colon tissue after 14 days of treatment. Abbreviations used in the figure: NC, negative control group (without UC induction); PC, positive control group (without treatment); N-EPS, UC induction with N-EPS treatment; A-EPS, UC induction with A-EPS treatment. The statistical analyses were performed using the Tukey-Kramer multiple comparisons test $\left({ }^{*} p<0.05\right)$. Data are indicated by mean \pm S.E. $(n=4-5)$.

\subsection{Difference in the Expression Level of Inflammatory-Related Cytokines}

In the preliminary animal experiment, we have confirmed the effectiveness of the IJH-SONE68-derived EPS, especially the A-EPS, in the disease activity index, as compared with EPSs from different LAB strains (Supplementary Figure S2). The preliminarily observed results correspond well to the data obtained in the present study; therefore, to understand the mechanism of the anti-inflammation activity observed with administration of the IJH-SONE68-derived EPS, we further investigated the gene-expression levels of some inflammatory cytokines in the colon tissue, using quantitative reverse transcriptional (qRT)PCR analysis (Figure 4). The expression level of mouse macrophage inflammatory protein 2 (MIP-2), which is a functional homolog of human IL-8, was approximately eight times higher in the PC group than in the NC group, showing that the difference was significant $(p<0.01)$. On the other hand, the administration of N- and A-EPSs resulted in the significantly low expression of MIP-2 (Figure 4A). 
A

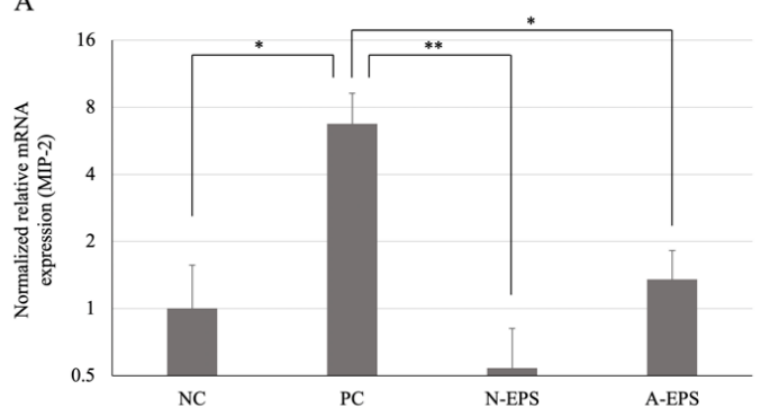

B

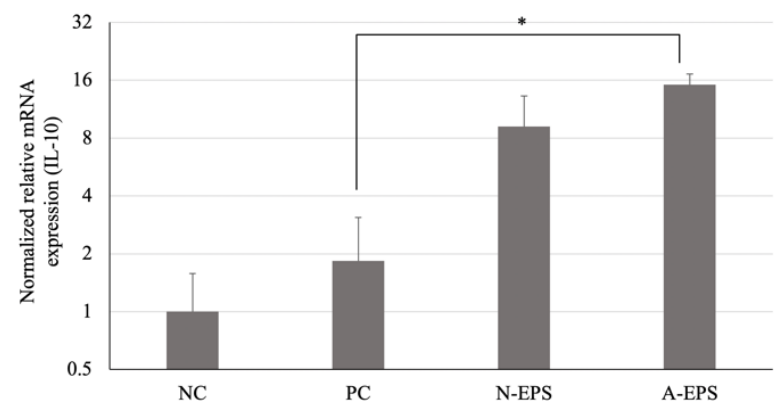

Figure 4. Effects of IJH-SONE68-derived EPSs in DSS-induced UC model mice on the mRNA level expressed in the colon tissue after 14 days of treatment. Each expression level of MIP-2 (A) and IL-10 (B) was normalized to that of the $\beta$-actin gene (reference gene) using the $\Delta \Delta C_{T}$ method. Abbreviations used in the figure: NC, negative control group (without UC induction); PC, positive control group (without treatment); N-EPS, UC induction with N-EPS treatment; A-EPS, UC induction with A-EPS treatment. The statistical analyses were performed using the Tukey-Kramer multiple comparison test $\left({ }^{*} p<0.05,{ }^{* *} p<0.01\right.$, vs. PC). Data are indicated by the mean \pm S.E. $(n=4-5)$.

Figure 4B indicates the expression levels of anti-inflammatory cytokine IL-10 in each group. In contrast to the case with MIP-2, the EPS administration relatively and significantly enhanced the IL-10 levels in the N- and A-EPS groups, respectively.

The expression levels of other inflammation-related cytokines and genes, including COX-2 and iNOS, were also measured, but no significant differences were observed in the EPS groups as compared with the NC and PC groups (Supplementary Figure S3).

\subsection{Histopathological Analysis of the Colon}

Pieces of mouse colon were fixed with formaldehyde and embedded in a paraffin block. The tissue sections were stained with HE and subjected to histopathological comparison (Figure 5).
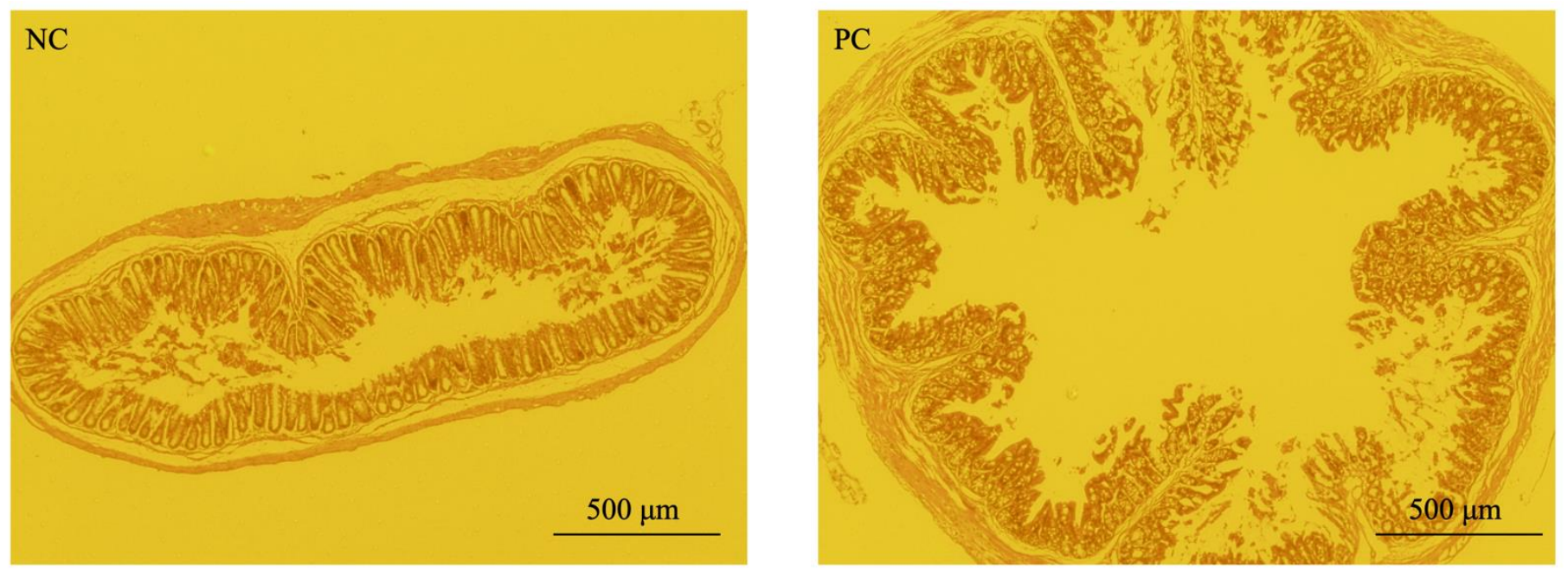

Figure 5. Cont. 

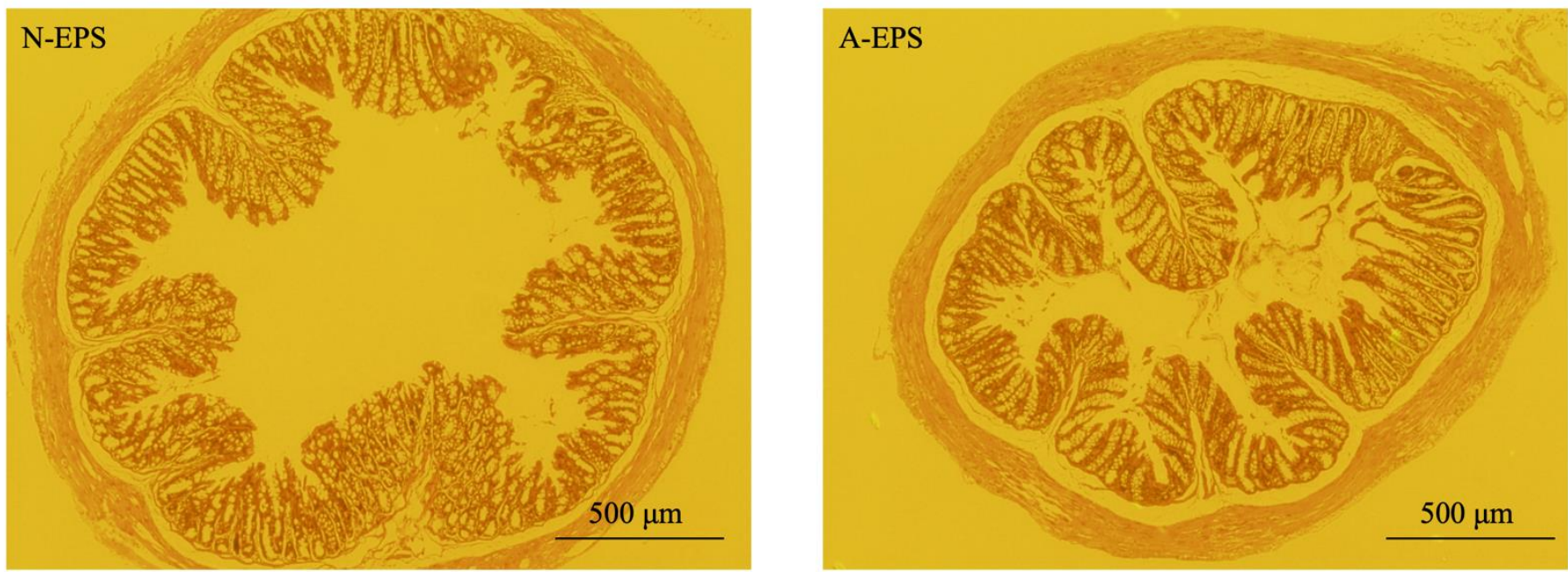

Figure 5. Effects of IJH-SONE68-derived EPSs on colonic tissue in DSS-induced UC model mice after 14 days of treatment. Representative colonic tissue sections were stained with hematoxylin and eosin. Abbreviations used in the figure: NC, negative control group (without UC induction); PC, positive control group (without treatment); N-EPS, UC induction with N-EPS treatment; A-EPS, UC induction with A-EPS treatment. Scale bar $=500 \mu \mathrm{m}$.

The analysis showed that DSS treatment causes histopathological injuries in the colon, such as denuding of the surface epithelium and disruption of the gland structure, which are typical characteristics of DSS-derived UC (PC in Figure 5). On the other hand, although the injury is still partially observed in the EPS-administration groups, the surface of the mucosa is covered with a relatively thick epithelial layer (N-EPS and A-EPS in Figure 5). Furthermore, EPS administration seemed to protect against the decrease in crypt depth that was also caused by DSS treatment (Figure 6). When compared with the NC group, the average crypt depth of the DSS-induced PC group decreased. However, the average depths observed in EPS-administration groups were increased significantly over those of the PC group.

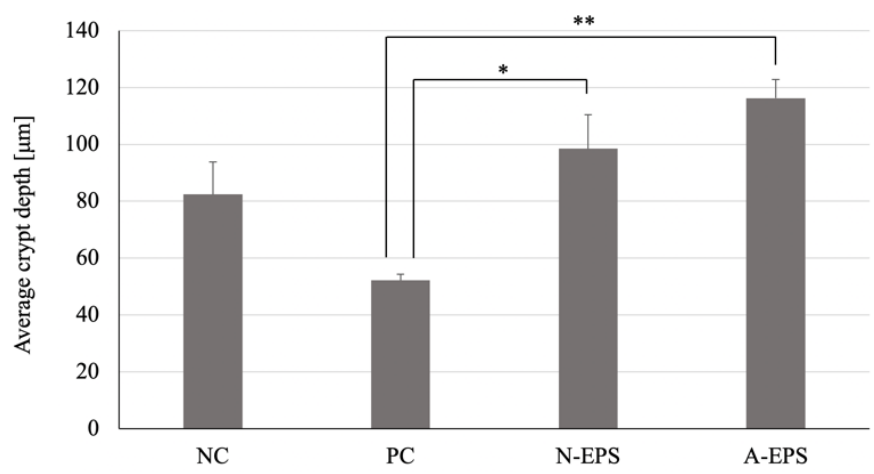

Figure 6. Effects of IJH-SONE68-derived EPSs in DSS-induced UC model mice on the average crypt depth after 14 days of treatment. Abbreviations used in the figure: NC, negative control group (without UC induction); PC, positive control group (without treatment); N-EPS, UC induction with N-EPS treatment; A-EPS, UC induction with A-EPS treatment. The statistical analyses were performed using the Tukey-Kramer multiple comparison test $\left({ }^{*} p<0.05,{ }^{* *} p<0.01\right.$, vs. PC). Data are indicated by the mean \pm S.E. $(n=4-5)$.

\section{Discussion}

Currently, due to the incurable nature of UC, the standard treatment aims to induce and maintain remission with medication. In mild to moderate UC, aminosalicylate drugs have been used as effective therapeutic agents [25-27]. In more severe cases, steroids, immuno-suppressive drugs, and biologics are often prescribed for patients. Sev- 
eral types of biologics, such as the TNF- $\alpha$ inhibitor infliximab or the $\alpha 4 \beta 7$ integrin inhibitor vedolizumab, are commonly used to treat UC patients who no longer respond to steroids [28]. Although these common agents have a high response rate in UC, some of them can cause serious side effects, such as extra-intestinal cancers, heart failure, and immune depression $[29,30]$. Therefore, demand for the development of safer and more effective anti-UC drugs has increased.

The UC model mice used in the present study showed a significantly higher expression level of colon MIP-2, which is a functional homolog of human IL-8, as compared to that in the negative control (Figure 4A), indicating a high correlation of the observed UC symptoms to the MIP-2 levels. On the other hand, the administration of IJH-SONE68-derived EPSs resulted in a significantly repressed MIP-2 expression level. In IBD patients, the number of infiltrated neutrophils significantly correlates with the IL-8 level in the homogenates of colonic biopsy specimens [31]. IL-8 can play a biological role through binding to IL-8 receptors $A$ and $B$ (also called CXCR1 and -2 , respectively), which locate on the cell surface of neutrophils $[32,33]$. Because the IL-8-CXCR1/2 signaling axis is involved not only in inflammatory diseases, including IBD, but also in carcinogenesis, its antagonists have been used as novel therapeutic targets for gastrointestinal tract inflammatory and malignant processes in clinical trials [34].

In contrast to MIP-2, the administration of each EPS enhanced IL-10 expression, especially in the A-EPS (Figure 4A). The IL-10-induction effect of the N-EPS was lower than that of the A-EPS, and the difference may cause a weaker preventive effect on the DAI, colon length, and MPO activity in both treated groups (Figures 1-3). It has been reported that the anti-inflammatory cytokine IL-10 may repress colitis inflammation in patients with UC [35]. In fact, genome-wide association studies (GWAS) of European patients have revealed that mutation in the IL-10 loci is associated with UC and CD [36,37]. The knockout of IL-10 in mice causes Th1- or Th17-type chronic inflammation and results in intestinal inflammation and colon cancer; therefore, mice have been used as one of the best animal models of IBD [38-42]. The intestinal macrophages from IL-10-deficient mice, which are characterized by immune dysregulation, produce large amounts of inflammatory cytokines in response to intestinal bacteria [43]. Although the exact regulatory mechanism of the EPS on cytokine expression is unknown, based on other studies of LAB-derived EPSs [44,45], including our previous report on contact dermatitis model mice [15], the IJH-SONE68-derived EPSs are expected to work through immune modulation.

Histopathological analysis (Figures 5 and 6) showed that DSS treatment injured the colon and caused a decrease in crypt depth. The crypt is a tube-like gland in the colon, and pluripotent stem cells are located at the bottom of the crypt. The stem cells have been reported to reproduce themselves and renew the colonic epithelium, providing tissue homeostasis and a mucosal barrier [46-48]. Since mis-migration often causes intestinal disorders such as IBD, the structure of the crypt pocket is crucial for protecting stem cells from various intestinal substances $[49,50]$. The present study indicates that the administration of EPSs promoted the formation of the epithelial layer and maintained the crypt length even after DSS treatment. As a potent regenerative agent, the R-spondin 1 protein (Rspo1) has been reported to promote repopulation of the mouse intestinal epithelium, resulting in the amelioration of inflammatory symptoms in not only DSS-induced experimental mice but also IL-10-deficient colitis model mice [51]. Porcine glucagon-like peptide-2 (pGLP-2) is expected to be a potentially effective agent against UC because of its therapeutic effect associated with increased crypt proliferation and the subsequent reduced production of inflammatory cytokines [52,53]. As therapeutic agents, the IJH-SONE68-derived EPSs are expected to have a protective effect on the colonic mucosa, with potent mitogenic activity in crypt cells.

The present study shows that the IJH-SONE68-derived EPS represses the release of IL-8 from the Caco-2 cells stimulated by S. Typhimurium or C. jejuni (Supplementary Figure S1), which have been reported to enter gut epithelial cells and impair the intestinal barrier $[54,55]$. The lipopolysaccharide (LPS) produced by these bacteria plays a major role during the inva- 
sion. It stimulates toll-like receptor-4 (TLR-4) in the host cell, which leads to inflammatory responses [56,57]. The Salmonella flagellin is recognized by TLR-5 as a pathogen-associated molecule, but the $C$. jejuni flagellin is not $[58,59]$. In bacterial invasion, TLRs interact with at least four types of adapter proteins. One of them is myeloid differentiation factor 88 (MyD88), which can be utilized by all TLRs $[60,61]$. Makino et al. reported that the EPS from Lb. delbrueckii subsp. bulgaricus OLL1073R-1 enhances the natural killer (NK) cell activity and interferon (IFN)- $\gamma$ production in mice [44] through the involvement of MyD88. Moreover, a TLR-4 homolog, RP105, has been reported to recognize not only the LPS but also the phosphorylated EPS from Lactococcus (Lc.) lactis subsp. cremoris GCL1176 [62]. Because no bactericidal activities were observed on the IJH-SONE68-derived EPSs, we speculate that the EPSs may play a role in the induction of some cytokines via the same pathway. Consequently, the inhibition of IL-8 release from Caco-2 cells and the UC prevention and improving effect in mice observed in the present study are suggested to be caused by the TLR- 4 signaling pathway, as previously predicted in contact dermatitis model mice [15].

The present result suggests that the A-EPS has more potent immune-modulating activity than the neutral one. This characteristic was also observed in a previous study using a contact dermatitis model [15]. In fact, some LAB-derived acidic EPSs have been reported to enhance NK cell activity and induce IFN- $\gamma$ and IL- $1 \alpha$ production [63-65]. However, the $L b$. plantarum No. 14-derived A-EPS and N-EPS, each of which has a different sugar composition and different acidic groups, have shown immunostimulatory activity on Peyer's patch cells and mesenteric lymph node cells [66]. We have confirmed the hyaluronidase-inhibitory effect on LAB-derived EPSs in previous studies [9-11], indicating that the inhibitory activity does not depend on the presence of acidic groups. Therefore, the functional activity of the EPS might be due to its structure or composition rather than its acidic properties.

Due to the disturbed intestinal microbiota, dysbiosis has been found to be one cause of UC. Some studies have demonstrated a benefit of human fecal microbiota transplantation (FMT) to induce remission in active UC [67]. The FMT technique has also been reported to be an effective treatment for other dysbiosis-associated disorders [68-70]. Since the exact roles of fecal microbiota have not been fully clarified, patients who have undergone FMT should be monitored carefully. In fact, a systematic review of FMT revealed that adverse effects are not rare, and the estimated mortality rate is estimated to be as high as 3.5\% [71]. Furthermore, following the death of a person who underwent FMT in 2019, the United States Food and Drug Administration (FDA) issued a safety alert about the potential for life-threatening infection with multidrug-resistant bacteria after FMT [72].

On the other hand, the therapeutic effect of probiotics has been studied in a number of clinical trials for the treatment of IBD $[73,74]$, showing that the use of probiotics might be recommended for anti-inflammatory therapy in UC patients. In addition to the probiotic cells, the EPS produced by LAB has been reported to confer health benefits such as immune modulation, enhanced NK cell activity, antimicrobial activity, and antitumor activity $[44,45,75]$. Furthermore, EPS-producing Lb. delbrueckii subsp. bulgaricus B3 and Bifidobacterium animalis A1dOxR can attenuate the oxidative stress in a colitis model and repress inflammatory cytokine production in the differentiated monolayer state of Caco-2 cells, respectively [76,77].

\section{Conclusions}

Lactobacillus paracasei IJH-SONE68 produces EPS that may have preventive and improving effects against DSS-induced UC model mice. Although more studies on the structural characterization and structure-function relationship of EPSs are needed, EPSs offer a promising lead for developing not only anti-UC drugs but also those effective against other diseases.

Supplementary Materials: The following are available online at https: / www.mdpi.com/article / 10.3390/microorganisms9112243/s1, Figure S1: Effects of the IJH-SONE68-derived EPS mixture on the IL-8 levels of a pathogen-stimulated Caco-2 cell line, Figure S2: Effects of LAB-derived 
EPSs in DSS-induced UC model mice on the changes in disease activity index, Figure S3: Effects of IJH-SONE68-derived EPSs in DSS-induced UC model mice on the mRNA level of (A) COX-2, (B) iNOS, (C) TNF- $\alpha$, (D) IL-6, (E) IL-12, (F) IL-17, and (G) IL-18 expressed in the colon tissue after 14 days of treatment.

Author Contributions: Conceptualization, M.N., N.D., T.U. and M.S.; methodology, M.N., N.D. and K.K.; validation, M.N. and N.D.; formal analysis, M.N. and N.D.; investigation, M.N. and N.D.; resources, T.U. and M.S.; writing-original draft preparation, M.N., N.D. and M.S.; writing—review and editing, M.N., N.D., K.K. and M.S.; project administration, M.S.; funding acquisition, T.U. and M.S. All authors have read and agreed to the published version of the manuscript.

Funding: This research received no external funding.

Institutional Review Board Statement: The animal experiment was conducted according to the guidelines of the Declaration of Helsinki, and its protocol was approved by the ethics committee of the Research Facilities for Laboratory Animal Science of Hiroshima University (approval number A18-2, approval on 3 April 2018).

Informed Consent Statement: Not applicable.

Data Availability Statement: The data presented in the study are available in article.

Acknowledgments: We thank the Research Center for Molecular Medicine, the Faculty of Medicine, and the Analysis Center of Life Science, Hiroshima University, for the use of their facilities.

Conflicts of Interest: The authors declare that the research was conducted in the absence of any commercial or financial relationship that could be construed as a potential conflict of interest.

\section{References}

1. Ng, S.C.; Shi, H.Y.; Hamidi, N.; Underwood, F.E.; Tang, W.; Benchimol, E.I.; Panaccione, R.; Ghosh, S.; Wu, J.C.Y.; Chan, F.K.L.; et al. Worldwide incidence and prevalence of inflammatory bowel disease in the 21st century: A systematic review of population-based studies. Lancet 2018, 390, 2769-2778. [CrossRef]

2. GBD 2017 Inflammatory Bowel Disease Collaborators. The global, regional, and national burden of inflammatory bowel disease in 195 countries and territories, 1990-2017: A systematic analysis for the Global Burden of Disease Study 2017. Lancet Gastroenterol. Hepatol. 2020, 5, 17-30. [CrossRef]

3. Baumgart, D.C.; Sandborn, W.J. Inflammatory bowel disease: Clinical aspects and established and evolving therapies. Lancet 2007, 369, 1641-1657. [CrossRef]

4. Noth, R.; Stüber, E.; Häsler, R.; Nikolaus, S.; Kühbacher, T.; Hampe, J.; Bewig, B.; Schreiber, S.; Arlt, A. Anti-TNF- $\alpha$ antibodies improve intestinal barrier function in Crohn's disease. J. Crohn's Colitis 2012, 6, 464-469. [CrossRef] [PubMed]

5. Salim, S.Y.; Söderholm, J.D. Importance of disrupted intestinal barrier in inflammatory bowel diseases. Inflamm. Bowel Dis. 2011, 17, 362-381. [CrossRef] [PubMed]

6. Mowat, C.; Cole, A.; Windsor, A.; Ahmad, T.; Arnott, I.; Driscoll, R.; Mitton, S.; Orchard, T.; Rutter, M.; Younge, L.; et al. Guidelines for the management of inflammatory bowel disease in adults. Gut 2011, 60, 571-607. [CrossRef] [PubMed]

7. Triantafillidis, J.K.; Merikas, E.; Georgopoulos, F. Current and emerging drugs for the treatment of inflammatory bowel disease. Drug Des. Dev. Ther. 2011, 5, 185-210. [CrossRef]

8. Sanders, M.E. Probiotics: Definition, sources, selection, and uses. Clin. Infect. Dis. 2008, 46, S58-S61. [CrossRef]

9. Panthavee, W.; Noda, M.; Danshiitsoodol, N.; Kumagai, T.; Sugiyama, M. Characterization of exopolysaccharides produced by thermophilic lactic acid bacteria isolated from tropical fruits of Thailand. Biol. Pharm. Bull. 2017, 40, 621-629. [CrossRef]

10. Noda, M.; Sugimoto, S.; Hayashi, I.; Danshiitsoodol, N.; Fukamachi, M.; Sugiyama, M. A novel structure of exopolysaccharide produced by a plant-derived lactic acid bacterium Lactobacillus paracasei IJH-SONE68. J. Biochem. 2018, 164, 87-92. [CrossRef]

11. Noda, M.; Shiraga, M.; Kumagai, T.; Danshiitsoodol, N.; Sugiyama, M. Characterization of the SN35N strain-specific exopolysaccharide encoded in the whole circular genome of a plant-derived Lactobacillus plantarum. Biol. Pharm. Bull. 2018, 41, 536-545. [CrossRef]

12. Kakegawa, H.; Matsumoto, H.; Satoh, T. Activation of hyaluronidase by metallic salts and compound 48/80, and inhibitory effect of anti-allergic agents on hyaluronidase. Chem. Pharm. Bull. 1985, 33, 642-646. [CrossRef]

13. Fujitani, N.; Sakaki, S.; Yamaguchi, Y.; Takenaka, H. Inhibitory effects of microalgae on the activation of hyaluronidase. J. Appl. Phycol. 2001, 13, 489-492. [CrossRef]

14. Maeda, Y.; Yamamoto, M.; Masui, T.; Sugiyama, K.; Yokota, M.; Nakagomi, K.; Tanaka, H.; Takahashi, I.; Kobayashi, T.; Kobayashi, E. Inhibitory effect of tea extracts on hyaluronidase. Shokuhin Eiseigaku Zashi 1990, 31, 233-237. [CrossRef]

15. Noda, M.; Sultana, N.; Hayashi, I.; Fukamachi, M.; Sugiyama, M. Exopolysaccharide produced by Lactobacillus paracasei IJHSONE68 prevents and improves the picryl chloride-induced contact dermatitis. Molecules 2019, 24, 2970. [CrossRef] [PubMed] 
16. Kimmel, S.A.; Roberts, R.F. Development of a growth medium suitable for exopolysaccharide production by Lactobacillus delbrueckii ssp. bulgaricus RR. Int. J. Food Microbiol. 1998, 40, 87-92. [CrossRef]

17. Kets, E.P.W.; Galinski, E.A.; de Bont, J.A.M. Carnitine: A novel compatible solute in Lactobacillus plantarum. Arch. Microbiol. 1994, 162, 243-248. [CrossRef]

18. Li, P.; Yu, Q.; Ye, X.; Wang, Z.; Yang, Q. Lactobacillus S-layer protein inhibition of Salmonella-induced reorganization of the cytoskeleton and activation of MAPK signaling pathways in Caco-2 cells. Microbiology 2011, 157, 2639-2646. [CrossRef] [PubMed]

19. Zhang, J.S.; Corredig, M.; Morales-Rayas, R.; Hassan, A.; Griffiths, M.W.; LaPointe, G. Effect of fermented milk from Lactococcus lactis ssp. cremoris strain JFR1 on Salmonella invasion of intestinal epithelial cells. J. Dairy Sci. 2019, 102, 6802-6819. [PubMed]

20. Kim, J.J.; Shajib, M.S.; Manocha, M.M.; Khan, W.I. Investigating intestinal inflammation in DSS-induced model of IBD. J. Vis. Exp. 2012, 60, 3678. [CrossRef]

21. Tukey, J.W. Comparing individual means in the analysis of variance. Biometrics 1949, 5, 99-114. [CrossRef]

22. Chassaing, B.; Aitken, J.D.; Malleshappa, M.; Vijay-Kumar, M. Dextran sulfate sodium (DSS)-induced colitis in mice. Curr. Protoc. Immunol. 2014, 104, 15.25.1-15.25.14. [CrossRef] [PubMed]

23. Okayasu, I.; Hatakeyama, S.; Yamada, M.; Ohkusa, T.; Inagaki, Y.; Nakaya, R. A novel method in the induction of reliable experimental acute and chronic ulcerative colitis in mice. Gastroenterology 1990, 98, 694-702. [CrossRef]

24. Smith, J.W.; Castro, G.A. Relation of peroxidase activity in gut mucosa to inflammation. Am. J. Physiol. 1978, 234, R72-R79. [CrossRef]

25. Khan, A.K.A.; Piris, J.; Truelove, S.C. An experiment to determine the active therapeutic moiety of sulphasalazine. Lancet 1977, 2, 892-895. [CrossRef]

26. Murray, A.; Nguyen, T.M.; Parker, C.E.; Feagan, B.G.; MacDonald, J.K. Oral 5-aminosalicylic acid for induction of remission in ulcerative colitis. Cochrane Database Syst. Rev. 2020, 8, CD000543. [PubMed]

27. Murray, A.; Nguyen, T.M.; Parker, C.E.; Feagan, B.G.; MacDonald, J.K. Oral 5-aminosalicylic acid for maintenance of remission in ulcerative colitis. Cochrane Database Syst. Rev. 2020, 8, CD000544. [PubMed]

28. Feuerstein, J.D.; Isaacs, K.L.; Schneider, Y.; Siddique, S.M.; Falck-Ytter, Y.; Singh, S.; AGA Institute Clinical Guidelines Committee. AGA clinical practice guidelines on the management of moderate to severe ulcerative colitis. Gastroenterology 2020, 158, 1450-1461. [CrossRef] [PubMed]

29. Axelrad, J.E.; Lichtiger, S.; Yajnik, V. Inflammatory bowel disease and cancer: The role of inflammation, immunosuppression, and cancer treatment. World J. Gastroenterol. 2016, 22, 4794-4801. [CrossRef] [PubMed]

30. Jiang, Y.; Lin, O.; Sinha, S.R. Use of tumor necrosis factor alpha inhibitors for inflammatory bowel disease patients with concurrent heart failure. Dig. Dis. Sci. 2017, 62, 1597-1606. [CrossRef] [PubMed]

31. Mitsuyama, K.; Toyonaga, A.; Sasaki, E.; Watanabe, K.; Tateishi, H.; Nishiyama, T.; Saiki, T.; Ikeda, H.; Tsuruta, O.; Tanikawa, K. IL-8 as an important chemoattractant for neutrophils in ulcerative colitis and Crohn's disease. Clin. Exp. Immunol. 1994, 96, 432-436. [CrossRef] [PubMed]

32. Waugh, D.J.J.; Wilson, C. The interleukin-8 pathway in cancer. Clin. Cancer Res. 2008, 14, 6735-6741. [CrossRef] [PubMed]

33. Acosta, J.C.; O’Loghlen, A.; Banito, A.; Guijarro, M.V.; Augert, A.; Raguz, S.; Fumagalli, M.; Da Costa, M.; Brown, C.; Popov, N.; et al. Chemokine signaling via the CXCR2 receptor reinforces senescence. Cell 2008, 133, 1006-1018. [CrossRef]

34. Cotton, J.A.; Platnich, J.M.; Muruve, D.A.; Jijon, H.B.; Buret, A.G.; Beck, P.L. Interleukin-8 in gastrointestinal inflammation and malignancy: Induction and clinical consequences. Int. J. Interferon Cytokine Mediat. Res. 2016, 8, 13-34.

35. Li, M.C.; He, S.H. IL-10 and its related cytokines for treatment of inflammatory bowel disease. World J. Gastroenterol. 2004, 10, 620-625. [CrossRef]

36. Franke, A.; Balschun, T.; Karlsen, T.H.; Sventoraityte, J.; Nikolaus, S.; Mayr, G.; Domingues, F.S.; Albrecht, M.; Nothnagel, M.; Ellinghaus, D.; et al. Sequence variants in IL10, ARPC2 and multiple other loci contribute to ulcerative colitis susceptibility. Nat. Genet. 2008, 40, 1319-1323. [CrossRef]

37. Franke, A.; McGovern, D.P.B.; Barrett, J.C.; Wang, K.; Radford-Smith, G.L.; Ahmad, T.; Lees, C.W.; Balschun, T.; Lee, J.; Roberts, R.; et al. Genome-wide meta-analysis increases to 71 the number of confirmed Crohn's disease susceptibility loci. Nat. Genet. 2010, 42, 1118-1125. [CrossRef] [PubMed]

38. Kühn, R.; Löhler, J.; Rennick, D.; Rajewsky, K.; Müller, W. Interleukin-10-deficient mice develop chronic enterocolitis. Cell 1993, 75, 263-274. [CrossRef]

39. Berg, D.J.; Davidson, N.; Kühn, R.; Müller, W.; Menon, S.; Holland, G.; Thompson-Snipes, L.; Leach, M.W.; Rennick, D. Enterocolitis and colon cancer in interleukin-10- deficient mice are associated with aberrant cytokine production and CD4(+) TH1-like responses. J. Clin. Investig. 1996, 98, 1010-1020. [CrossRef] [PubMed]

40. Yen, D.; Cheung, J.; Scheerens, H.; Poulet, F.; McClanahan, T.; Mckenzie, B.; Kleinschek, M.A.; Owyang, A.; Mattson, J.; Blumenschein, W.; et al. IL-23 is essential for T cell-mediated colitis and promotes inflammation via IL-17 and IL-6. J. Clin. Investig. 2006, 116, 1310-1316. [CrossRef]

41. Kullberg, M.C.; Jankovic, D.; Feng, C.G.; Hue, S.; Gorelick, P.L.; McKenzie, B.S.; Cua, D.J.; Powrie, F.; Cheever, A.W.; Maloy, K.J.; et al. IL-23 plays a key role in Helicobacter hepaticus-induced T cell-dependent colitis. J. Exp. Med. 2006, 203, 2485-2494. [CrossRef]

42. Ogino, H.; Nakamura, K.; Ihara, E.; Akiho, H.; Takayanagi, R. CD4 ${ }^{+}$CD25 $5^{+}$regulatory T cells suppress Th17-responses in an experimental colitis model. Dig. Dis. Sci. 2011, 56, 376-386. [CrossRef] 
43. Kamada, N.; Hisamatsu, T.; Okamoto, S.; Sato, T.; Matsuoka, K.; Arai, K.; Nakai, T.; Hasegawa, A.; Inoue, N.; Watanabe, N.; et al. Abnormally differentiated subsets of intestinal macrophage play a key role in Th1-dominant chronic colitis through excess production of IL-12 and IL-23 in response to bacteria. J. Immunol. 2005, 175, 6900-6908. [CrossRef]

44. Makino, S.; Sato, A.; Goto, A.; Nakamura, M.; Ogawa, M.; Chiba, Y.; Hemmi, J.; Kano, H.; Takeda, K.; Okumura, K.; et al. Enhanced natural killer cell activation by exopolysaccharides derived from yogurt fermented with Lactobacillus delbrueckii ssp. bulgaricus OLL1073R-1. J. Dairy Sci. 2016, 99, 915-923. [CrossRef]

45. Vinderola, G.; Perdigón, G.; Duarte, J.; Farnworth, E.; Matar, C. Effect of the oral administration of the exopolysaccharide produce by Lactobacillus kefiranofaciens on the gut mucosal immunity. Cytokine 2006, 36, 254-260. [CrossRef]

46. Sasaki, S.; Yoneyama, H.; Suzuki, K.; Suriki, H.; Aiba, T.; Watanabe, S.; Kawauchi, Y.; Kawachi, H.; Shimizu, F.; Matsushima, K.; et al. Blockade of CXCL10 protects mice from acute colitis and enhances crypt cell survival. Eur. J. Immunol. 2002, 32, 3197-3205. [CrossRef]

47. Potten, C.S. Stem cells in gastrointestinal epithelium: Numbers, characteristics and death. Philos. Trans. R. Soc. Lond. B. 1998, 353, 821-830. [CrossRef]

48. Snippert, H.J. Colonic Crypts: Safe Haven from Microbial Products. Cell 2016, 165, 1564-1566. [CrossRef]

49. Hermiston, M.L.; Gordon, J.I. Inflammatory bowel diseases and adenomas in mice expressing a dominant negative N-cadherin. Science 1995, 270, 1203-1207. [CrossRef]

50. Hermiston, M.L.; Wong, M.H.; Gordon, J.I. Forced expression of E-cadherin in the mouse intestinal epithelium slows cell migration and provides evidence for nonautonomous regulation of cell fate in a self-renewing system. Genes Dev. 1996, 10, 985-996. [CrossRef]

51. Zhao, J.; de Vera, J.; Narushima, S.; Beck, E.X.; Palencia, S.; Shinkawa, P.; Kim, K.A.; Liu, Y.; Levy, M.D.; Berg, D.J.; et al. R-spondin1, a novel intestinotrophic mitogen, ameliorates experimental colitis in mice. Gastroenterology 2007, 132, $1331-1343$. [CrossRef]

52. Qi, K.; Lv, J.; Wu, J.; Xu, Z. Therapeutic effects of different doses of polyethylene glycosylated porcine glucagon-like peptide-2 on ulcerative colitis in male rats. BMC Gastroenterol. 2017, 17, 34. [CrossRef]

53. L'Heureux, M.C.; Brubaker, P.L. GLP-2 and DSS glucagon-like peptide-2 and common therapeutics in a murine model of ulcerative colitis. J. Pharmacol. Exp. Ther. 2003, 306, 347-354. [CrossRef]

54. Tafazoli, F.; Magnusson, K.E.; Zheng, L. Disruption of epithelial barrier integrity by Salmonella enterica serovar Typhimurium requires geranylgeranylated proteins. Infect. Immun. 2003, 71, 872-881. [CrossRef]

55. Harrer, A.; Bücker, R.; Boehm, M.; Zarzecka, U.; Tegtmeyer, N.; Sticht, H.; Schulzke, J.D.; Backert, S. Campylobacter jejuni enters gut epithelial cells and impairs intestinal barrier function through cleavage of occludin by serine protease HtrA. Gut Pathog. 2019, 11, 4. [CrossRef]

56. Freudenberg, M.A.; Merlin, T.; Gumenscheimer, M.; Kalis, C.; Landmann, R.; Galanos, C. Role of lipopolysaccharide susceptibility in the innate immune response to Salmonella typhimurium infection: LPS, a primary target for recognition of Gram-negative bacteria. Microb. Infect. 2001, 3, 1213-1222. [CrossRef]

57. Rathinam, V.A.K.; Appledorn, D.M.; Hoag, K.A.; Amalfitano, A.; Mansfield, L.S. Campylobacter jejuni-induced activation of dendritic cells involves cooperative signaling through Toll-like receptor 4 (TLR4)-MyD88 and TLR4-TRIF axes. Infect. Immun. 2009, 77, 2499-2507. [CrossRef] [PubMed]

58. Wick, M.J. Living in the danger zone: Innate immunity to Salmonella. Curr. Opin. Microb. 2004, 7, 51-57. [CrossRef] [PubMed]

59. De Zoete, M.R.; Keestra, A.M.; Wagenaar, J.A.; van Putten, J.P.M. Reconstitution of a functional toll-like receptor 5 binding site in Campylobacter jejuni flagellin. J. Biol. Chem. 2010, 285, 12149-12158. [CrossRef]

60. Deguine, J.; Barton, G.M. MyD88: A central player in innate immune signaling. F1000Prime Rep. 2014, 6, 97. [CrossRef] [PubMed]

61. O'Neill, L.A.; Bowie, A.G. The family of five: TIR-domain-containing adaptors in Toll-like receptor signaling. Nat. Rev. Immunol. 2007, 7, 353-364. [CrossRef]

62. Tohno, M.; Shimizu, T.; Ueda, W.; Anzawa, D.H.; Aso, H.; Nishimura, J.; Kawai, Y.; Saito, Y.; Saito, T.; Kitazawa, H. Molecular cloning of porcine RP105/MD-1 involved in recognition of extracellular phosphopolysaccharides from Lactococcus lactis ssp. cremoris. Mol. Immunol. 2007, 44, 2566-2577. [CrossRef]

63. Makino, S.; Ikegami, S.; Kano, H.; Sashihara, T.; Sugano, H.; Horiuchi, H.; Saito, T.; Oda, M. Immunomodulatory effects of polysaccharides produced by Lactobacillus delbrueckii ssp. bulgaricus OLL1073R-1. J. Dairy Sci. 2006, 89, 2873-2881. [CrossRef]

64. Kitazawa, H.; Harata, T.; Uemura, J.; Saito, T.; Kaneko, T.; Itoh, T. Phosphate group requirement for mitogenic activation of lymphocytes by an extracellular phosphopolysaccharide from Lactobacillus delbrueckii ssp. bulgaricus. Int. J. Food Microbiol. 1998, 40, 169-175. [CrossRef]

65. Kitazawa, H.; Itoh, T.; Tomioka, Y.; Mizugaki, M.; Yamaguchi, T. Induction of IFN- $\gamma$ and IL- $1 \alpha$ production in macrophages stimulated with phosphopolysaccharide produced by Lactococcus lactis ssp. cremoris. Int. J. Food Microbiol. 1996, 31, 99-106. [CrossRef]

66. Hashiguchi, K.; Nagata, Y.; Yoshida, M.; Murohushi, Y.; Kitazawa, H. Chemical and immunological characterization of extracellular polysaccharides produced by Lactobacillus plantarum No 14. Jpn. J. Lact. Acid Bact. 2011, 22, 100-105. [CrossRef]

67. Narula, N.; Kassam, Z.; Yuan, Y.; Colombel, J.F.; Ponsioen, C.; Reinisch, W.; Moayyedi, P. Systematic review and meta-analysis: Fecal microbiota transplantation for treatment of active ulcerative colitis. Inflamm. Bowel Dis. 2017, 23, 1702-1709. [CrossRef] 
68. Ianiro, G.; Maida, M.; Burisch, J.; Simonelli, C.; Hold, G.; Ventimiglia, M.; Gasbarrini, A.; Cammarota, G. Efficacy of different faecal microbiota transplantation protocols for Clostridium difficile infection: A systematic review and meta-analysis. United Eur. Gastroenterol. J. 2018, 6, 1232-1244. [CrossRef]

69. Cammarota, G.; Ianiro, G.; Tilg, H.; Rajilić-Stojanović, M.; Kump, P.; Satokari, R.; Sokol, H.; Arkkila, P.; Pintus, C.; Hart, A.; et al. European consensus conference on faecal microbiota transplantation in clinical practice. Gut 2017, 66, 569-580. [CrossRef] [PubMed]

70. Kootte, R.S.; Levin, E.; Salojärvi, J.; Smits, L.P.; Hartstra, A.V.; Udayappan, S.D.; Hermes, G.; Bouter, K.E.; Koopen, A.M.; Holst, J.J.; et al. Improvement of insulin sensitivity after lean donor feces in metabolic syndrome is driven by baseline intestinal microbiota composition. Cell Metab. 2017, 26, 611-619. [CrossRef]

71. Wang, S.; Xu, M.; Wang, W.; Cao, X.; Piao, M.; Khan, S.; Yan, F.; Cao, H.; Wang, B. Systematic review: Adverse events of fecal microbiota transplantation. PLoS ONE 2016, 11, e0161174. [CrossRef]

72. FDA. Important Safety Alert Regarding Use of Fecal Microbiota for Transplantation and Risk of Serious Adverse Reactions Due to Transmission of Multi-Drug Resistant Organisms; U.S. Food \& Drug Administration: Hampton, VA, USA, 2019.

73. Pabón-Carrasco, M.; Ramirez-Baena, L.; Vilar-Palomo, S.; Castro-Méndez, A.; Martos-García, R.; Rodríguez-Gallego, I. Probiotics as a coadjuvant factor in active or quiescent inflammatory bowel disease of adults-A meta-analytical study. Nutrients 2020, 12, 2628. [CrossRef]

74. Emamie, A.D.; Rajabpour, M.; Ghanavati, R.; Asadolahi, P.; Farzi, S.; Sobouti, B.; Darbandi, A. The effects of probiotics, prebiotics and synbiotics on the reduction of IBD complications, a periodic review during 2009-2020. J. Appl. Microbiol. 2020, 130, 1823-1838. [CrossRef]

75. Furukawa, N.; Matsuoka, A.; Takahashi, T.; Yamanaka, Y. Anti-metastatic effect of kefir grain components on Lewis lung carcinoma and highly metastatic B16 melanoma in mice. J. Agric. Sci. Tokyo Univ. Agric. 2020, 45, 62-70.

76. Sengül, N.; Işık, S.; Aslım, B.; Uçar, G.; Demirbağ, A.E. The effect of exopolysaccharide-producing probiotic strains on gut oxidative damage in experimental colitis. Dig. Dis. Sci. 2011, 56, 707-714. [CrossRef] [PubMed]

77. Hidalgo-Cantabrana, C.; López, P.; Gueimonde, M.; de Los Reyes-Gavilán, C.G.; Suárez, A.; Margolles, A.; Ruas-Madiedo, P. Immune modulation capability of exopolysaccharides synthesised by lactic acid bacteria and bifidobacteria. Probiotics Antimicrob. Proteins 2012, 4, 227-237. [CrossRef] 